\title{
Climate change effects on snow conditions in main- land Australia and adaptation at ski resorts through snowmaking
}

\author{
K. J. Hennessy ${ }^{1, *}$, P. H. Whetton ${ }^{1}$, K. Walsh ${ }^{2}$, I. N. Smith ${ }^{1}$, J. M. Bathols ${ }^{1}$, \\ M. Hutchinson ${ }^{3}$, J. Sharples ${ }^{3}$ \\ ${ }^{1}$ CSIRO Marine and Atmospheric Research, PB 1, Aspendale, 3195 Victoria, Australia \\ ${ }^{2}$ School of Earth Sciences, University of Melbourne, Acton, 3010 Victoria, Australia \\ ${ }^{3}$ Australian National University Centre for Resource and Environmental Studies, The Australian National University, \\ Canberra, 0200 ACT, Australia
}

\begin{abstract}
We examined the effects of past and future climate change on natural snow cover in southeastern mainland Australia and assessed the role of snowmaking in adapting to projected changes in snow conditions. Snow-depth data from 4 alpine sites from 1957 to 2002 indicated a weak decline in maximum snow depths at 3 sites and a moderate decline in mid- to late-season snow depths (August to September). Low-impact and high-impact climate change scenarios were prepared for 2020 and 2050 and used as input for a climate-driven snow model. The total area with an average of at least 1 d of snow cover per year was projected to decrease by 10 to $39 \%$ by 2020, and by 22 to $85 \%$ by 2050 . By 2020 , the length of the ski season was projected to have decreased by 10 to $60 \%$, while by 2050 the decrease was 15 to $99 \%$. Based on target snow-depth profiles from May to September nominated by snowmaking managers at various ski resorts, the snow model simulated the amount of snow that is needed to be made each day, taking into account natural snowfall, snow-melt and the pre-existing natural snow depth. By the year 2020, an increase of 11 to $27 \%$ in the number of snow guns would be required for the low impact scenario, and 71 to $200 \%$ for the high impact scenario. This corresponds to changes in total snow volume of 5 to $17 \%$ for the low impact scenario to 23 to $62 \%$ for the high impact scenario. Therefore, with sufficient investment in snow guns, the Australian ski industry may be able to manage the effect of projected climate change on snow cover until at least 2020.
\end{abstract}

KEY WORDS: Snow $\cdot$ Depth $\cdot$ Area $\cdot$ Duration $\cdot$ Australia $\cdot$ Climate $\cdot$ Change $\cdot$ Snowmaking

\section{INTRODUCTION}

During the past $100 \mathrm{yr}$, the Earth's average temperature has risen by $0.7^{\circ} \mathrm{C}$ (Jones \& Moberg 2003), with the period 1996-2005 containing the 9 warmest years on record (WMO 2005). The Intergovernmental Panel on Climate Change concluded that 'an increasing body of observations gives a collective picture of a warming world and other changes in the climate system' (IPCC 2001, p. 2), and that this warming was largely manmade and due to the enhanced greenhouse effect. The complexity of processes in the climate system means it is inappropriate to simply extrapolate past trends to forecast future conditions. This has led to the development of climate change scenarios (CIAP 1975, CSIRO 2001), which allow analysis of 'what if?' questions based on various assumptions about demographic change, economic growth and technological change. Plausible future emissions scenarios (e.g. SRES; IPCC 2000) indicate that concentrations of greenhouse gases will continue to increase in the 21st century, leading to further global warming and other changes in regional climate (IPCC 2001).

Changes in snow cover due to climate change have been observed in recent decades. Satellite measurements indicate a $\sim 5 \%$ decline in northern hemisphere 
annual snow-cover extent since 1966, largely due to decreases in spring and summer snow cover since the mid-1980s over both the Eurasian and American continents (Robinson \& Frei 2000). Surface observations for the northern hemisphere from 1915-1992 show no significant change in winter snow extent, but a decrease in spring (Brown 2000). At most locations below $1800 \mathrm{~m}$ in northwestern USA, large decreases in waterequivalent snow depth from 1950-2000 coincide with significant increases in temperature, despite increases in precipitation (Groisman et al. 2004, Mote et al. 2005). Since the late 1940s, there has been a shift toward earlier snow-melt runoff in many rivers of northwestern America (Stewart et al. 2005).

In the Australian region, there has been a warming of $0.9^{\circ} \mathrm{C}$ since 1900 , most of which has occurred since 1950 (Nicholls \& Collins 2006). Australian rainfall exhibits large annual and regional variability, including a decline in annual rainfall in the east since 1950 (Nicholls \& Collins, 2006). Climate trends are likely to have had an effect on the Australian snowfields, but the large annual variability in snow season characteristics in the mainland Australian alpine region makes it difficult to detect trends. Fig. 1 shows a map of the Australian alpine region. Ruddell et al. (1990) showed that snow depths had declined at some sites from the 1950 s to 1989 , but no trends were statistically significant at the $90 \%$ confidence level. Davis (1998) found a decrease in the number of Snowy Mountain snowfall days from 1970 to 1996, particularly in May and August. Slater (1995) estimated that snow depth had declined $25 \%$ at Spencers Creek between 1954 and 1993, while Green (2000) noted a decreasing trend in integrated weekly snow depth, measured in metredays, at Spencers Creek from 1959 to 1999. Nicholls (2005) noted a $40 \%$ decline in spring snow cover at
Spencers Creek in the past $40 \mathrm{yr}$, and attributed most of it to warming rather than to changes in precipitation.

A number of European studies have investigated the impacts of future warming on snow conditions (e.g. Abegg 1996, Bürki 2000, Steiger 2004), while the Canadian study of Scott et al. (2003) examined the effectiveness of snowmaking as an adaptation strategy. The impact of future climate change on Australian snow cover was assessed by Whetton (1998), using the CSIRO (1996) climate change scenarios and the CSIRO snow model (Whetton et al. 1996). Whetton (1998) estimated that the total area with snow cover for at least $30 \mathrm{~d} \mathrm{yr}^{-1}$ in southeast Australia could decline by 18 to $66 \%$ by 2030 , and by 39 to $96 \%$ by 2070 . This was based on a warming of 0.3 to $1.3^{\circ} \mathrm{C}$ and 0.6 to $3.4^{\circ} \mathrm{C}$ by 2030 and 2070, respectively, and a precipitation change of between 0 and $-8 \%$ and 0 and $-20 \%$, respectively. Since that time, CSIRO has modified its climate change scenarios (CSIRO 2001) and the snow model has been improved. Given that most of southeastern Australia has continued to warm over the past decade (Nicholls \& Collins 2006), an updated

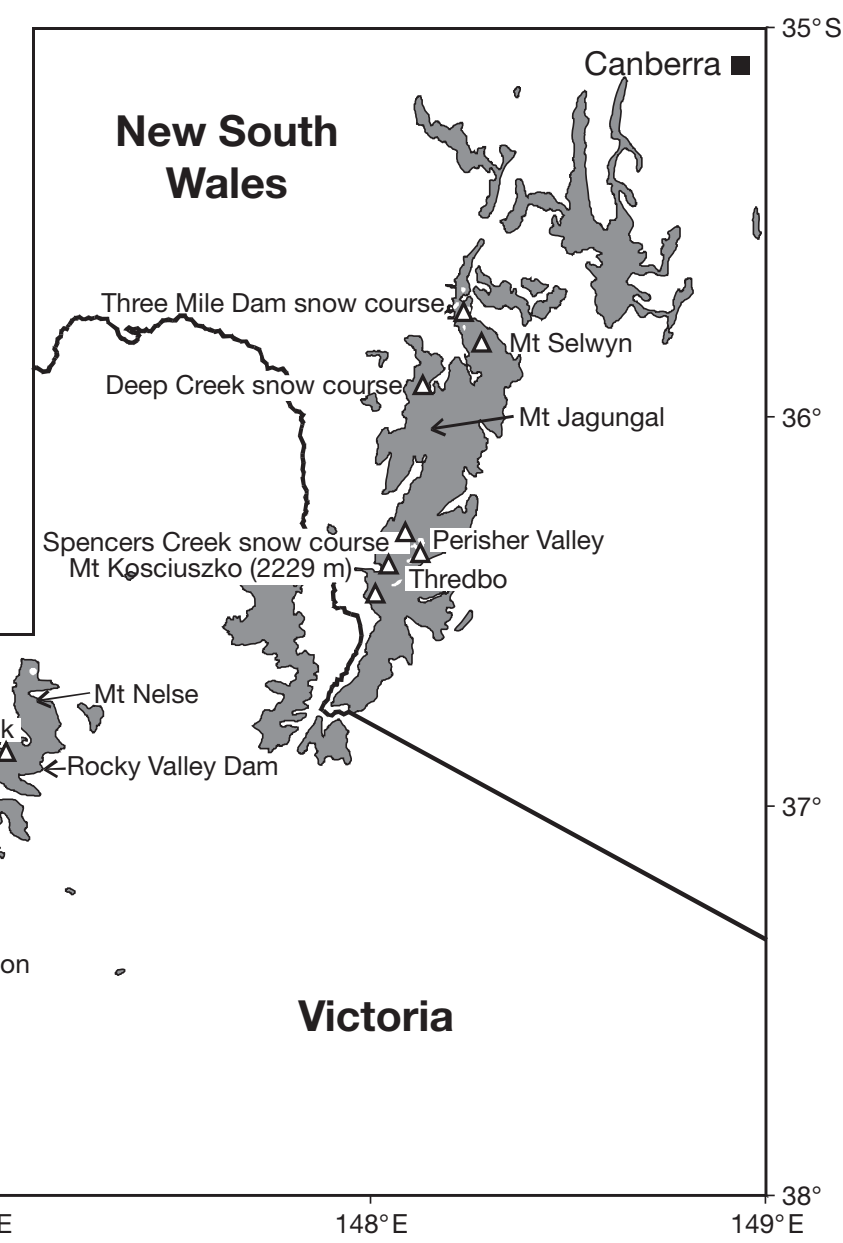

Fig. 1. Study region and alpine sites referred to in this paper (modified from Ruddell et al. 1990, with permission from the University of Melbourne). Land at $>1400$ m elevation (grey) is usually snow-covered for at least 1 mo per year 
assessment of snow trends is needed to show whether there has been any change in the rate of decline, and whether these trends continue to be consistent with projections based on greenhouse warming.

The ski season in the Australian alpine region typically lasts from early June to early October, although at low elevations the season is shorter and often discontinuous. Typically, a minimum operational depth for alpine skiing is approximately $30 \mathrm{~cm}$, although this varies considerably depending on terrain, and is lower for cross-country ski resorts (Australian Ski Areas Association pers. comm.). Current snowmaking needs are substantial at each of the major ski resorts, with increased investment in recent years. For example, whilst 2006 was a very poor snow season in terms of natural snowfall in comparison with the previous $9 \mathrm{yr}$, the resorts at higher elevations were able to use their extensive snowmaking systems to establish a reasonable snow base early in the snow season-about $50 \%$ of the snow depth throughout 2006 was produced artificially (ARCC 2007).

In this study, projections of changes in natural snow cover and depth are estimated for 2020 and 2050. The scope for adaptation through increased snowmaking at ski resorts by 2020 is also assessed, as well as the implications for longer-term natural resource management. Section 2 describes the data and methods, Section 3 details the validation of the snow model, Section 4 assesses observed alpine trends and model projections of future snow cover, Section 5 discusses the impact of climate change on snowmaking, and Section 6 contains a brief discussion and conclusions.

\section{DATA AND METHODS}

Databases developed by Australian National University Centre for Resource and Environmental Studies (ANU CRES) provided elevation, temperature, and precipitation on a 1/40th degree grid (about $2.5 \mathrm{~km}$ ). The monthly climate grids, spanning 1951-2000, were created by fitting elevation dependent thin plate smoothing splines to climate station data recorded by the Australian Bureau of Meteorology (Hutchinson 1991, 2001, McKenney et al. 2006) and then calculating the surfaces on a digital elevation model. Further details are available from Hennessy et al. (2003). While daily climate grids would have been preferable, the relatively sparse daily observation network across the study area did not allow the creation of reliable daily gridded data. However, daily weather variability is incorporated into the snow model (described below). Snow depth data were supplied by Southern Hydro and by the Snowy Mountains Hydroelectric Authority, but measurement errors in snow data can be as high as $50 \%$ under some conditions (Sevruk 1982).
The CSIRO snow model was developed by Whetton et al. (1996) from the model of Galloway (1988). The model is used to calculate daily snow cover duration and water-equivalent snow depth from monthlyaverage temperature and precipitation, and monthly standard deviation of daily temperature. Standard deviation of temperature was used in the estimation of the average temperature of days with precipitation (see Whetton et al. 1996 for more details). Empirically derived relationships incorporating these parameters are used to calculate accumulation (snowfall) and ablation (melting and evaporation of snow) for each month. Accumulation depends on monthly precipitation and the proportion of precipitation falling as snow (which is temperature dependent). Ablation is calculated from the number of degree-days $>0{ }^{\circ} \mathrm{C}$. The snow season begins when accumulation exceeds ablation, and the snow depth grows until ablation exceeds accumulation. The snow depth then falls until the excess of ablation over accumulation has been sufficient to melt all snow, at which point the season ends.

One of the previously identified limitations of the model was the underestimation of snow depths and durations at lower elevation sites, such as Lake Mountain. It was recommended by Haylock et al. (1994, p. 26) that 'shorter simulated durations (< 30 d) should simply be viewed as 'marginal' and not interpreted literally'. A key aim of the present study was to improve the performance of the CSIRO snow model at low-elevation sites, and this was achieved by including daily sequences of precipitation and by using more accurate monthly input climate data generated at the ANU. A feature of the new model has been to change snow depth units from water-equivalent to snow-equivalent, thereby giving more relevant results for resort operators and natural resource managers. As a result of changes to the model, the new version gives a more realistic simulation of the marginal depths in low snow years.

The CSIRO (2001) climate change scenarios incorporate 3 sources of uncertainty: (1) the IPCC (2001) range of climate sensitivity (a global warming of 1.5 to $4.5^{\circ} \mathrm{C}$ for a doubling of carbon dioxide concentration from $280 \mathrm{ppm}$ to $560 \mathrm{ppm}$ ); (2) the SRES (IPCC 2000) range of 40 greenhouse gas and aerosol emissions scenarios; and (3) differences between climate models in their regional patterns of climate change. The IPCC (2001) range of global warming for 1990-2100 combines (1) and (2). To estimate (3) for the Australian alpine region, regional patterns of climate change from 9 climate models were expressed as a change per ${ }^{\circ} \mathrm{C}$ of global-average warming. To estimate regional changes in temperature and precipitation for 2020 and 2050 , the regional patterns of change per ${ }^{\circ} \mathrm{C}$ of globalaverage warming were scaled by IPCC (2001) global warming values for the individual years 2020 and 
2050. This pattern scaling method is considered robust (Mitchell 2003). Australian alpine climate change projections are shown in Table 1.

For snow, the low impact scenario is the combination of the lowest warming and the greatest precipitation increase, while the high impact scenario is the highest warming combined with the greatest precipitation decrease. The snow model was driven by gridded monthly temperature and precipitation data from 1979 to 1998, modified by the climate change projections in Table 1. Results for 2020 are of greatest relevance to future management of ski resorts due to the smaller range of uncertainty in the projected changes in temperature and precipitation. Projections to 2050 are also of interest to the ski industry and to managers of conservation estates that have high ecological value, but these projections are associated with greater uncertainty.

\section{SNOW MODEL VALIDATION}

A basic test of model performance is how well it reproduces the average snow-depth profile. Examples are shown in Fig. 2 for 6 sites in Victoria and New South Wales. The model performs well at all New South Wales and north-eastern Victorian sites where observed snow-depth data were available for validation, i.e. Mount Perisher, Mount Thredbo, Deep Creek, Mount Hotham, Falls Creek, Mount Buller and Three Mile Dam.

However, at southern Victorian mountains such as Mount Baw Baw and Lake Mountain, average snow depths and season lengths were underestimated. This could be due to problems with the input climate data (temperatures too high and/or precipitation too low) and/or a deficiency in the snow model at low elevations. The latter is unlikely since the model performs well at low elevations in New South Wales (e.g. Three Mile Dam). Closer investigation revealed that, while the ANU-derived temperature values were realistic, the ANU-derived precipitation was not increasing with elevation as much as expected in southern Victoria. This conclusion was reached on the basis of the mis-

Table 1. Projected changes in Australian alpine temperature and precipitation for 2020 and 2050, relative to 1990. See Section 2 for description of low- and high-impact scenarios

\begin{tabular}{|lccc|}
\hline Scenario & Year & $\begin{array}{c}\Delta \text { Temperature } \\
\left({ }^{\circ} \mathrm{C}\right)\end{array}$ & $\begin{array}{c}\Delta \text { Precipitation } \\
(\%)\end{array}$ \\
\hline Low impact & 2020 & +0.2 & +0.9 \\
& 2050 & +0.6 & +2.3 \\
High impact & 2020 & +1.0 & -8.3 \\
& 2050 & +2.9 & -24.0 \\
\hline
\end{tabular}

match between the model-derived output and the observed snow profile. The most likely reason is the sparsity of high-elevation precipitation observations in southern Victoria, which requires precipitation in the ANU dataset to be extrapolated from low-elevation records.

In addition, it was considered that the monthly temperature data, which are used in the snow model to estimate the fraction of precipitation falling as snow, gives less accurate results for this fraction in the southern alpine region as opposed to the region as a whole. Sensitivity tests indicate that the observed snow profiles at Mount Baw Baw and Mount Wellington were well simulated when the ANU-derived precipitation data were increased by $20 \%$ and when the temperature data were lowered by $0.5^{\circ} \mathrm{C}$. The Lake Mountain profile was more realistic when ANU-derived precipitation data were increased by $20 \%$ and when the temperature data were lowered by $1.0^{\circ} \mathrm{C}$. In the southern Australian alpine region, the overwhelming majority of snowfall occurs on days of below-average temperature, whereas snowfall is more evenly distributed with respect to temperature at the higher elevations of the northern alpine region. This implies that the snow model, which was calibrated over the entire alpine region using monthly-average data, would give less snow than observed in the southern alpine region. The use of daily data for calibration would probably reduce this bias. ANU and CSIRO are seeking records of highelevation weather data in southern Victoria so that the ANU precipitation grid can be improved. In the meantime, for the purposes of this study, we have applied the above-mentioned precipitation and temperature corrections so that the simulated snow profiles are more realistic at Mount Baw Baw, Mount Wellington and Lake Mountain. Amounts are also under-simulated at Spencers Creek. This may be due to the effects of aspect and exposure on the observation site, which for snowfall can be highly site-specific.

\section{RESULTS}

\subsection{Current climate trends in mainland Australian snowfields}

An analysis was performed of trends in observed June to September climate from 1962 to 2001 in the region of the Australian alpine region shown in Fig. 1. Positive temperature trends were evident in most months at 4 sites with elevations between 200 and $850 \mathrm{~m}$, and at 4 sites between 1380 and $2000 \mathrm{~m}$. The alpine trends ( 1380 to $2000 \mathrm{~m}$ ) were close to $+0.2^{\circ} \mathrm{C}$ per decade, with greatest increases in September. These trends were larger than those at 200 to 850 m (Hen- 

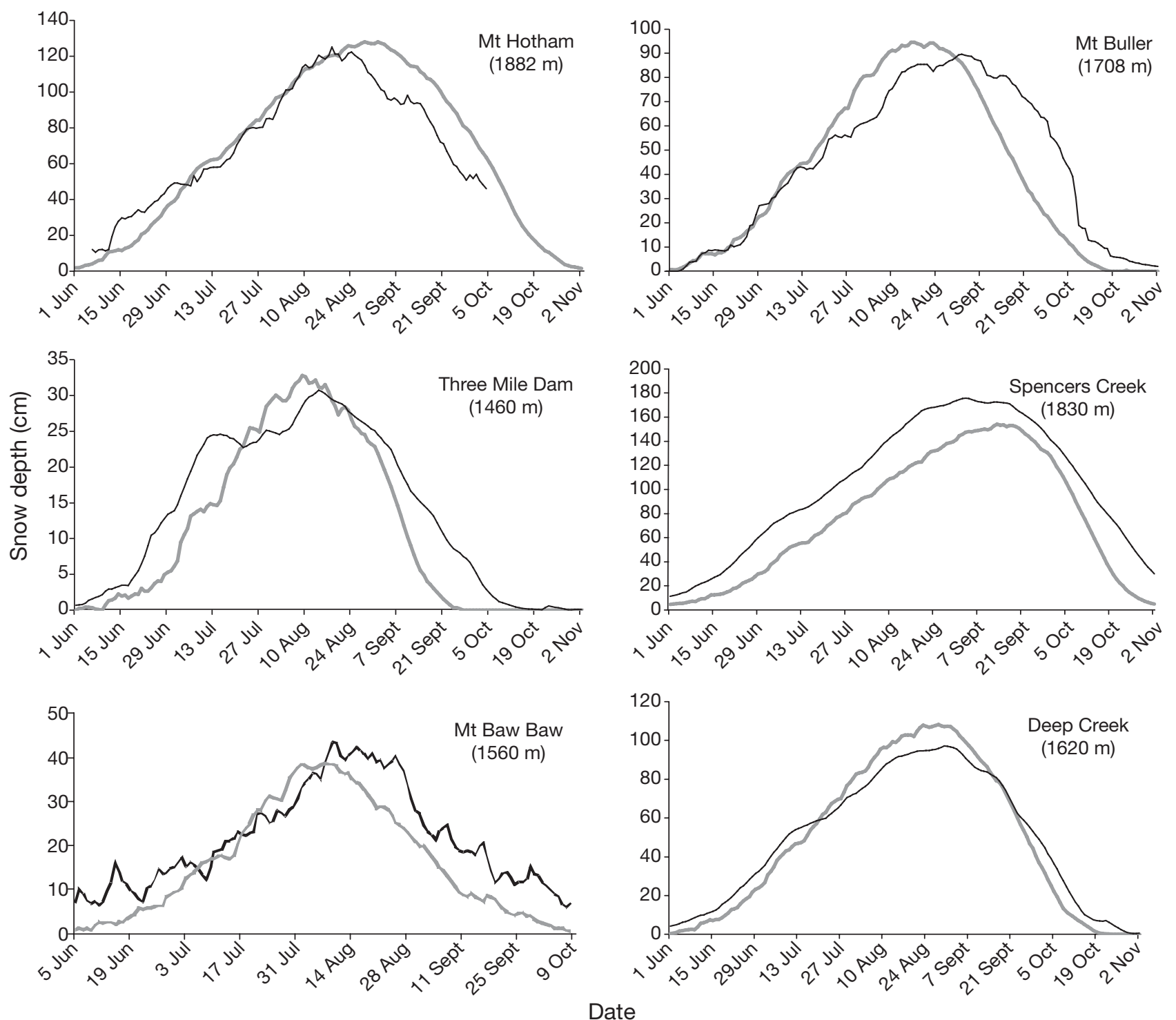

Fig. 2. Comparison of simulated (grey) and observed (black) snow depths at Mount Hotham, Mount Buller, Mount Baw Baw (Victoria), and Three Mile Dam, Spencers Creek, and Deep Creek (NSW). Data are for 1979-1998, except for Mt Hotham Observed (1988-2002) and Mt Baw Baw Simulated (1993-2002). Note different $y$-axis scales

nessy et al. 2003). For June to September between 1951 and 2000, small increases in alpine precipitation occurred in the northern alpine region and small decreases in the southern alpine region.

Analysis of maximum snow-depth data from 1957 to 2002 at Deep Creek, Three Mile Dam, Rocky Valley Dam and Spencers Creek gave trends of +0.9 , $-0.7,-3.3$ and $-4.3 \mathrm{~cm}$ decade $^{-1}$, respectively (Fig. 3). These trends represent percentage changes of +0.7 , $-1.3,-2.8$ and $-2.2 \%$ decade $^{-1}$ respectively. None of the trends was statistically significant at the $90 \%$ confidence level. Snow-depth data were converted to water-equivalent data using an average snowdensity factor of 0.4 (Ruddell et al. 1990). Table 2 shows that the decline in maximum snow depth slowed in the 1990s at Three Mile Dam, Rocky Valley Dam and Spencers Creek, and reversed at Deep Creek.

Table 2. Trends in water-equivalent maximum snow depth (DC: Deep Creek; TMD: Three Mile Dam; RVD: Rocky Valley Dam; SC: Spencers Creek). Units are per decade. Values for 1957 to 1989 taken from Ruddell et al. (1990)

\begin{tabular}{|lcccc|}
\hline Site & \multicolumn{2}{c}{1957 to 1989} & \multicolumn{2}{c|}{2002} \\
& $(\mathrm{~cm})$ & $(\%)$ & $(\mathrm{cm})$ & $(\%)$ \\
\hline DC & -0.5 & -1.00 & +0.4 & +0.70 \\
TMD & -0.5 & -2.90 & -0.3 & -1.30 \\
RVD & -5.4 & -11.10 & -1.3 & -2.80 \\
SC & -6.8 & -7.40 & -1.7 & -2.20 \\
\hline
\end{tabular}



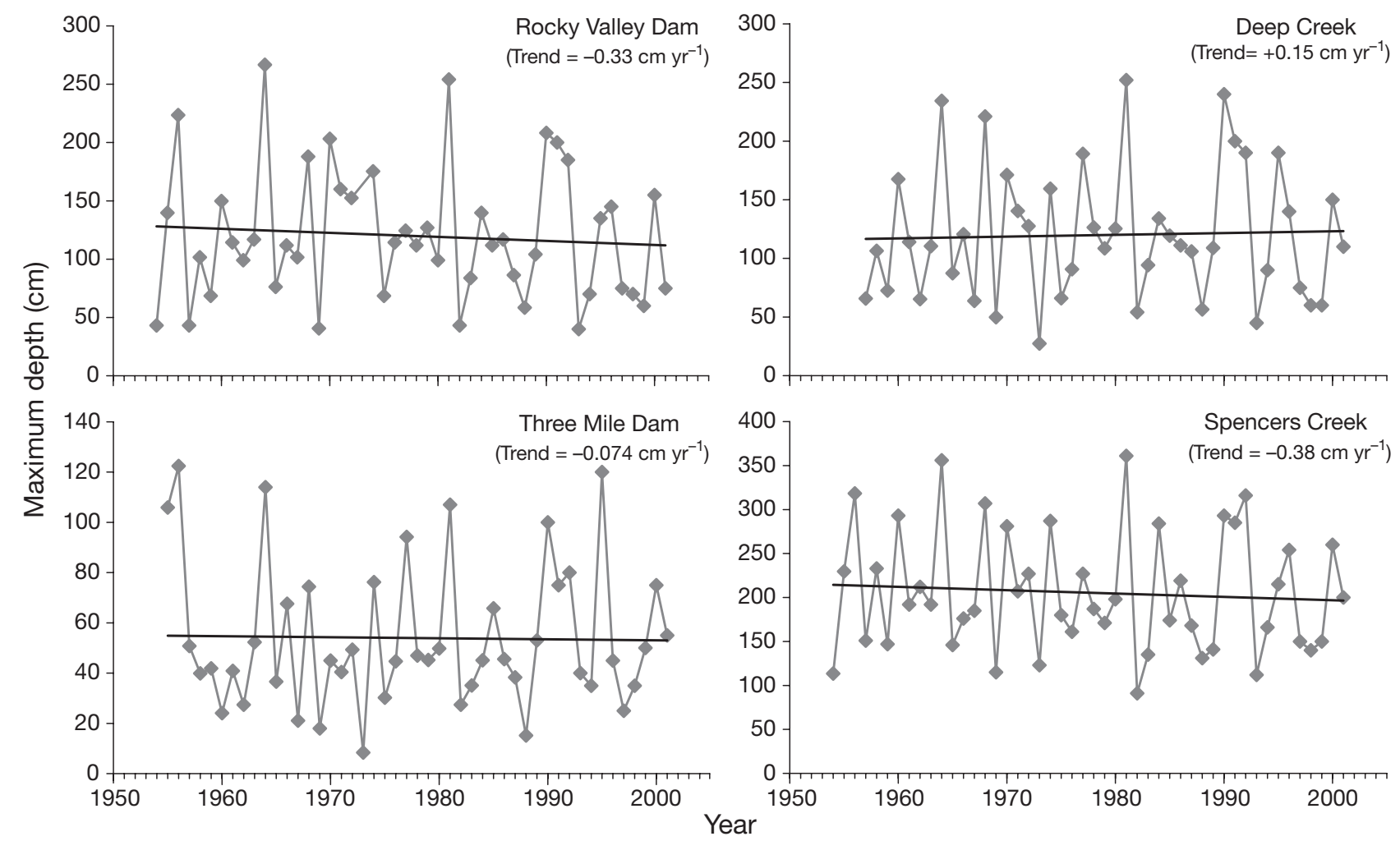

Fig. 3. Observed maximum snow depth (cm) at Rocky Valley Dam (elevation $1650 \mathrm{~m})$, Deep Creek (1620 m), Three Mile Dam $(1460 \mathrm{~m})$ and Spencers Creek $(1830 \mathrm{~m})$. Note different $y$-axis scales

Because maximum snow depth usually occurs during late August, trends in maximum snow depth may not be the best indicator of changes in the snow profile at other times of the year, nor of the length of the season. Since the mid-1950s, trends in snow depth on 1 July, 1 August and 1 September at Spencers Creek, Three Mile Dam and Deep Creek showed a decline in August and September (Table 3). The decrease on 1 August at these stations ranged from 5.6 to $9.1 \mathrm{~cm}$ decade $^{-1}$, while on 1 September the decrease ranged from 2.6 to $4.6 \mathrm{~cm} \mathrm{decade}^{-1}$. The moderate decline in August and September snow depths may indicate the tendency for mid to late season snow depth to be determined by temperature-dependent ablation (melt and

Table 3. Trends in snow depth $\left(\mathrm{cm} \mathrm{decade}{ }^{-1}\right)$ on selected dates at selected sites (DC: Deep Creek, SC: Spencers Creek, TMD: Three Mile Dam). Daily data for Rocky Valley Dam were unavailable. ${ }^{*}$ Significant at $97 \%$ confidence level

\begin{tabular}{|lccccc|}
\hline Site & \multirow{2}{*}{\begin{tabular}{c}
\multirow{2}{*}{ Elevation } \\
$(\mathrm{m})$
\end{tabular}} & Period & \multicolumn{3}{c|}{$\Delta$ snow depth } \\
& & & 1 Jul $)$ & 1 Aug & 1 Sep \\
\hline SC & 1830 & $1954-2002$ & -4.3 & -9.1 & -4.6 \\
DC & 1620 & $1957-2002$ & +5.6 & -5.6 & -2.7 \\
TMD & 1460 & $1955-2002$ & +0.3 & $-5.7^{*}$ & -2.6 \\
& & & & & \\
\hline
\end{tabular}

evaporation), which has likely been increasing due to rising temperatures. In contrast, the depth of early season snow is determined by precipitation, which has shown only weak trends.

\subsection{Simulated snow depth and duration}

Simulated regional patterns of snow-cover duration, for depths $>1 \mathrm{~cm}$, are shown in Fig. $4 \mathrm{a}$ for the present, and for the 2020 and 2050 high- and low-impact scenarios. Depending on the scenario chosen, the total area with an average of at least $1 \mathrm{~d}$ of snow cover decreases 10 to $39 \%$ by 2020 and 22 to $85 \%$ by 2050 (Table 4 ).

Table 4. Percent change in area with at least 1,30 or $60 \mathrm{~d}$ simulated annual-average snow-cover duration for 2020 and 2050, relative to 1990. Low, High: low- and high-impact scenarios

\begin{tabular}{|c|c|c|c|c|}
\hline \multirow{3}{*}{$\begin{array}{l}\text { Snow cover } \\
\text { (d) }\end{array}$} & \multirow{2}{*}{\multicolumn{2}{|c|}{2020}} & \multirow{2}{*}{\multicolumn{2}{|c|}{2050}} \\
\hline & & & & \\
\hline & Low & High & Low & High \\
\hline$>1$ & -9.9 & -39.3 & -22.0 & -84.7 \\
\hline$>30$ & -14.4 & -54.4 & -29.6 & -93.2 \\
\hline$>60$ & -17.5 & -60.3 & -38.1 & -96.3 \\
\hline
\end{tabular}



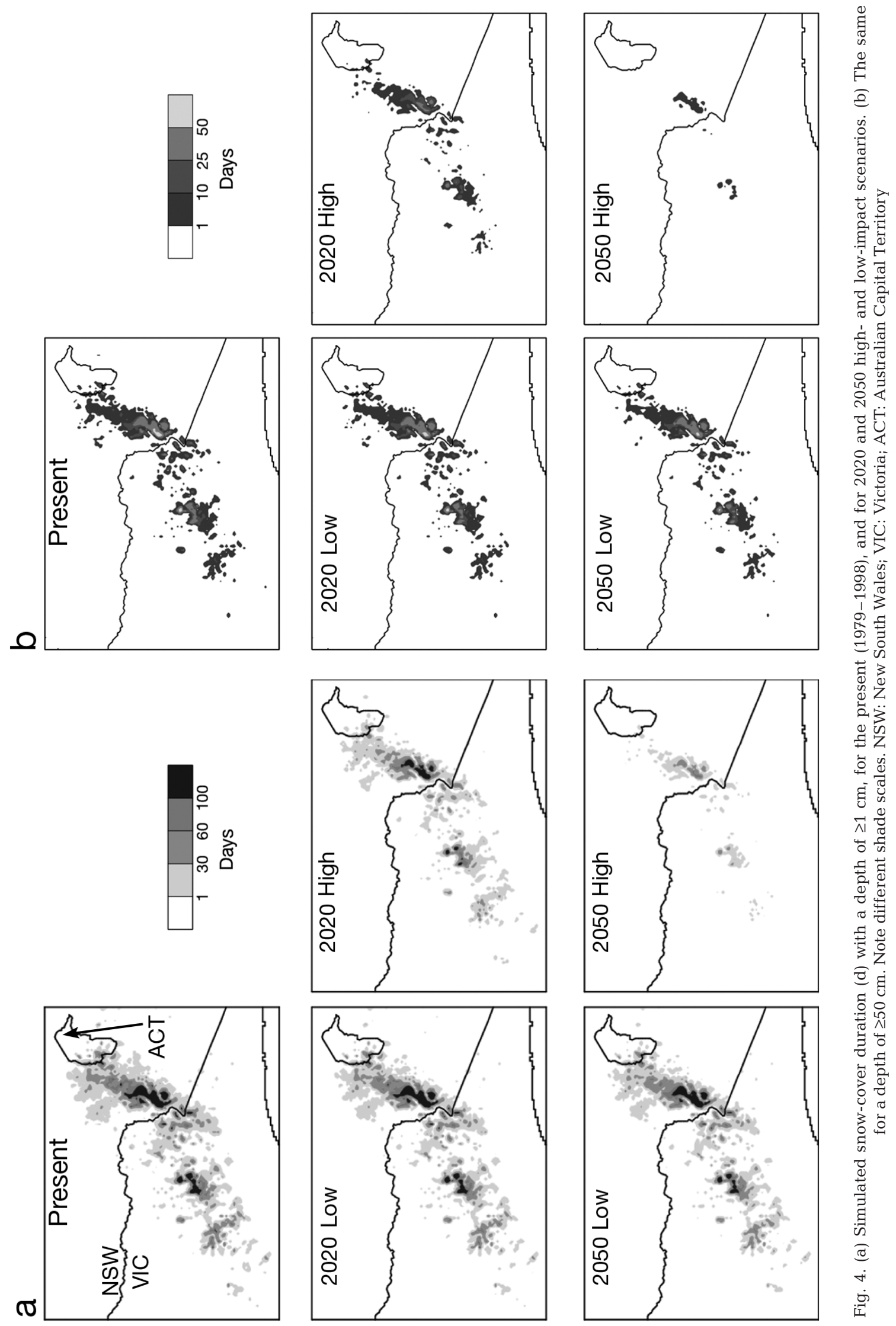
The area with at least $30 \mathrm{~d}$ of snow cover decreases 14 to $54 \%$ by 2020 and 30 to $93 \%$ by 2050 , while the area with at least $60 \mathrm{~d}$ of cover decreases 18 to $60 \%$ by 2020 and 38 to $96 \%$ by 2050 .

An estimate of the length of the ski season can be obtained from Fig. 4b, which shows the same plot for a snow depth of $\geq 50 \mathrm{~cm}$. Few Australian snowfields have a natural snow depth of $50 \mathrm{~cm}$ over an average of at least $50 \mathrm{~d}$ in the present climate. Thus Australian ski resorts depend heavily on snow making to maintain a viable season length. For 2020, the number of days with $\geq 50 \mathrm{~cm}$ snow decreases only slightly in the low impact scenario, but becomes quite noticeable in the high impact scenario, while under the 2050 high impact scenario, only the highest areas have any days on average with more than $50 \mathrm{~cm}$ of snow.

Site-specific results were calculated for 9 alpine ski resorts, each of which has significant ecological attributes, such as populations of the mountain pygmypossum and alpine she-oak skink, as well as alpine snow-patch communities (Green \& Pickering 2002). The Victorian resorts are Lake Mountain, Mount Baw Baw, Mount Buller, Mount Buffalo, Falls Creek and Mount Hotham, while the New South Wales resorts are Mount Thredbo, Mount Perisher and Mount Selwyn. Results were also calculated for 5 other locations of ecological significance to provide information for alpine management: Mount Wellington and Mount Nelse in Victoria, and Whites River Valley, Mount Jagungal and Mount Kosciuszko (Australia's highest mountain) in New South Wales. Fig. 5 shows the annual-average snow-depth profiles for 2 alpine sites, the high altitude Mount Kosciuszko, and the low altitude Mount Baw Baw. Results for other sites listed above are available in Hennessy et al. (2003). Profiles for present conditions were averaged over the period from 1979 to 1998 and profiles for the future were created using climate data from the same 20 yr modified by the climate change scenarios. Table 5 shows average duration of snow cover at all sites.

By the year 2020, the average ski season length is reduced by 5 to $50 \mathrm{~d}$. This represents a 10 to $60 \%$ reduction at sites below $1600 \mathrm{~m}$ (e.g. Mount Baw Baw) and 5 to $30 \%$ at sites above $1600 \mathrm{~m}$ (e.g. Mount Kosciuszko or Mount Hotham). Impacts on peak depth follow a similar pattern: moderate impacts at higher elevation sites, large impacts at lower elevation sites. Maximum snow depths decline by 15 to $80 \%$ at sites below $1600 \mathrm{~m}$ and 5 to $50 \%$ at sites above $1600 \mathrm{~m}$, with a tendency for maximum snow depth to occur earlier in the season. For example, at Mount Thredbo, maximum snow depth occurs about 20 d earlier under the high impact scenario. There is also a tendency for depth reductions to be larger toward the end of the season, which is consistent with observed trends. The percentage reductions in season length are larger than the 0 to $16 \%$ decrease by the 2020s derived by Scott et al. (2003) for the Ontario ski area in Canada using similar methods, but different climate change scenarios, a different snow model, and a higher latitude region.

By the year 2050, average season lengths decrease by 15 to $110 \mathrm{~d}$. This represents a 30 to $99 \%$ reduction at sites below $1600 \mathrm{~m}$ and 15 to $95 \%$ at sites above $1600 \mathrm{~m}$. Reductions in peak depths range from 10 to $100 \%$.
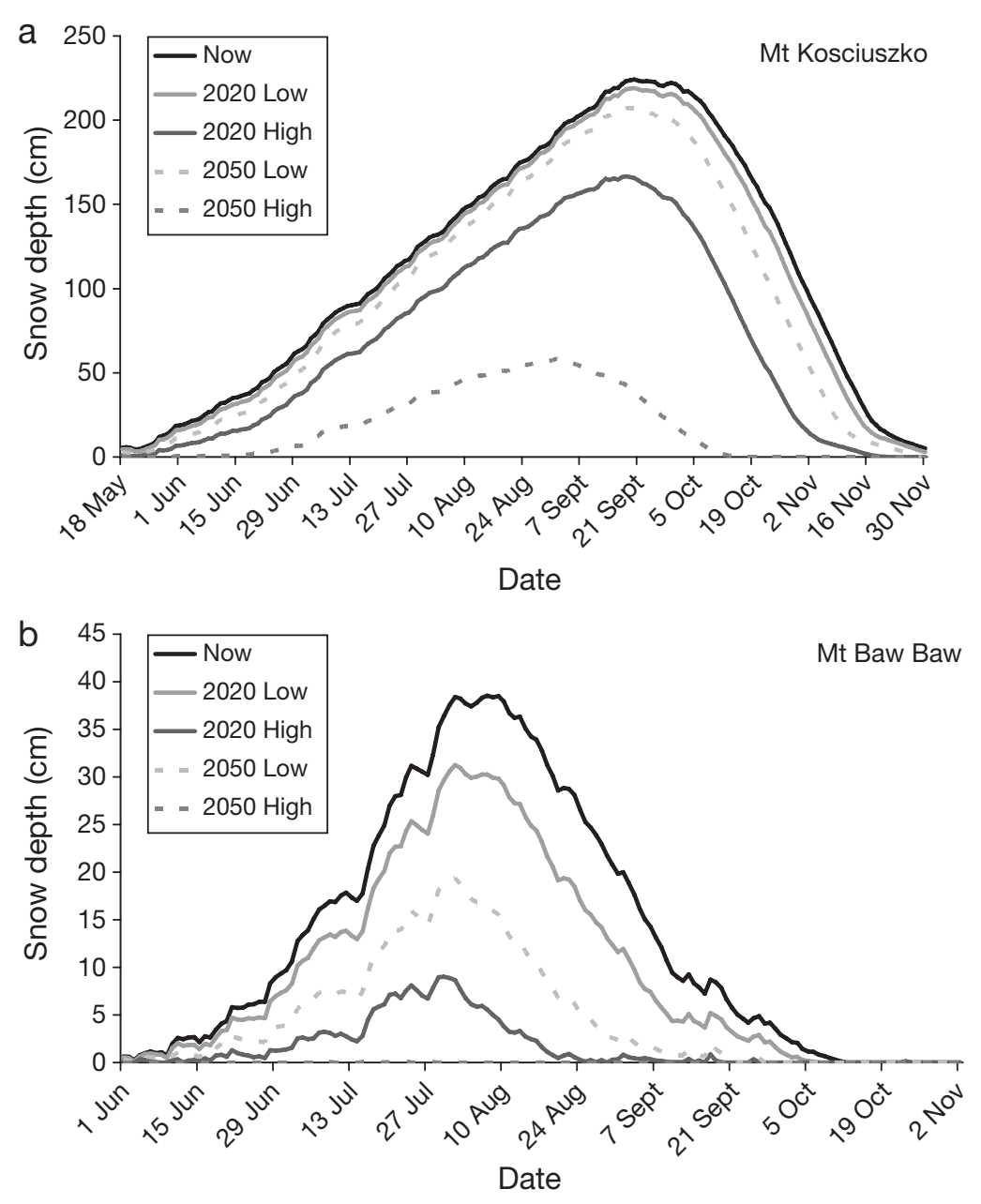

Fig. 5. Simulated $20 \mathrm{yr}$ average snow-depth profiles at for the present (1979-1998), and for the 2020 and 2050 high- and low-impact scenarios at (a) Mount Kosciuszko (elevation 2228 m); and (b) Mount Baw Baw (1560 m). Note different axis scales 
Table 5. Simulated average duration of $\geq 1 \mathrm{~cm}$ of snow cover for the present (1979-1998), 2020 and 2050 at selected resorts and sites of ecological significance. Lower, Mid, Higher: relative range of elevations (not available for all sites). Mount Wellington values are for the high plains

\begin{tabular}{|c|c|c|c|c|c|}
\hline \multirow[t]{2}{*}{ Site } & \multicolumn{2}{|c|}{ Elevation } & \multicolumn{3}{|c|}{$-1 \mathrm{~cm}$ snow cover $(\mathrm{d})-$} \\
\hline & Rel. & $(\mathrm{m})$ & Present & 2020 & 2050 \\
\hline \multicolumn{2}{|l|}{ Lake Mountain } & 1400 & 74 & $30-66$ & $1-48$ \\
\hline \multicolumn{2}{|l|}{ Mt Baw Baw } & 1560 & 80 & $32-71$ & $1-53$ \\
\hline \multirow{3}{*}{ Mt Buller } & Lower & 1383 & 33 & $7-25$ & $0-15$ \\
\hline & Mid & 1560 & 76 & $36-67$ & $1-56$ \\
\hline & Higher & 1740 & 108 & $70-102$ & $7-89$ \\
\hline \multirow[t]{3}{*}{ Mt Buffalo } & Lower & 1477 & 70 & $29-63$ & $0-50$ \\
\hline & Mid & 1516 & 80 & $39-73$ & $1-59$ \\
\hline & Higher & 1723 & 113 & $78-108$ & $10-96$ \\
\hline \multirow{2}{*}{\multicolumn{2}{|c|}{$\begin{array}{l}\text { Mt Wellington } \\
\text { Mt Nelse }\end{array}$}} & 1560 & 82 & $38-75$ & $2-59$ \\
\hline & & 1829 & 133 & $101-128$ & $27-117$ \\
\hline \multirow[t]{3}{*}{ Falls Creek } & Lower & 1504 & 77 & $41-71$ & $2-59$ \\
\hline & Mid & 1643 & 105 & $68-99$ & $8-87$ \\
\hline & Higher & 1797 & 125 & $92-120$ & $18-108$ \\
\hline \multirow[t]{3}{*}{ Mt Hotham } & Lower & 1400 & 51 & $15-44$ & $0-29$ \\
\hline & Mid & 1650 & 98 & $59-92$ & $4-77$ \\
\hline & Higher & 1882 & 129 & $97-124$ & 21-114 \\
\hline \multirow[t]{3}{*}{ Mt Perisher } & Lower & 1605 & 90 & $53-87$ & $4-69$ \\
\hline & Mid & 1835 & 131 & $100-125$ & $30-115$ \\
\hline & Higher & 2021 & 151 & $122-146$ & $56-136$ \\
\hline \multirow[t]{3}{*}{ Mt Thredbo } & Lower & 1350 & 32 & $8-26$ & $0-17$ \\
\hline & Mid & 1715 & 113 & 80-108 & $13-97$ \\
\hline & Higher & 2023 & 153 & $122-148$ & $56-138$ \\
\hline \multicolumn{2}{|l|}{ Mt Selwyn } & 1604 & 81 & $43-74$ & $3-60$ \\
\hline \multicolumn{2}{|l|}{$\begin{array}{l}\text { Whites River } \\
\text { Valley }\end{array}$} & 1746 & 118 & $88-113$ & $18-103$ \\
\hline \multicolumn{2}{|l|}{ Mt Jagungal } & 2061 & 156 & $128-151$ & $65-141$ \\
\hline \multicolumn{2}{|l|}{ Mt Kosciuszko } & 2228 & 183 & $153-178$ & $96-169$ \\
\hline
\end{tabular}

there was little variation between sites in the height of the snowline with warming.

The probability of exceeding a natural snow depth of $30 \mathrm{~cm}$ each day was calculated for Mount Hotham using data for 1979-1998 (Fig. 7). For example, on 1 September, 18 of the $20 \mathrm{yr}$ had at least $30 \mathrm{~cm}$ of snow, so the present probability was estimated as $90 \%$. By 2020 , this probability may decline to between 60 and $85 \%$. On 1 July, the probability drops from the present value of $65 \%$ to 15 to $60 \%$ by 2020 .

Other results (not shown) include an increase in the proportion of rain to snow and an increase in the rate of ablation as the climate warms (Hennessy et al. 2003).

\section{PROJECTED CHANGES IN SNOWMAKING REQUIREMENTS}

\subsection{Introduction}

Elsasser \& Bürki (2002) found that $85 \%$ of Switzerland's ski resorts can currently be designated as having reliable natural snow, but this may decline to $44 \%$ over the coming decades if the elevation of reliable snow rises $600 \mathrm{~m}$ due to greenhouse warming. They concluded that climate change should be viewed as a catalyst for reinforcing and accelerating the pace of structural changes in alpine tourism. Greenhouse warming over the coming decades will require adaptation by the ski industry through various operational and technical advances, many of which have been ongoing in the past decade, such as snowmaking.

Snowmaking is used in Australia to supplement natural snow cover on heavily used or low-elevation

\subsection{Other aspects of simulated snow conditions}

The daily elevation of the snowline was estimated for Mount Hotham by identifying the lowest snow-covered gridpoint within $25 \mathrm{~km}$. Results were averaged over the 20 yr period 1979-1998 and plotted as a snowline profile throughout the year (Fig. 6). The results show that the snowline may rise from the present 1 September average of $1410 \mathrm{~m}$ to between 1440 and $1600 \mathrm{~m}$ by 2020. At Mount Selwyn (not shown), the snowline on 1 September rises from $1415 \mathrm{~m}$ at present to between 1500 and $1660 \mathrm{~m}$ by 2020. At Mount Kosciuszko (not shown), the snowline on 1 September rises from $1460 \mathrm{~m}$ at present to between 1490 and $1625 \mathrm{~m}$ by 2020. As expected,

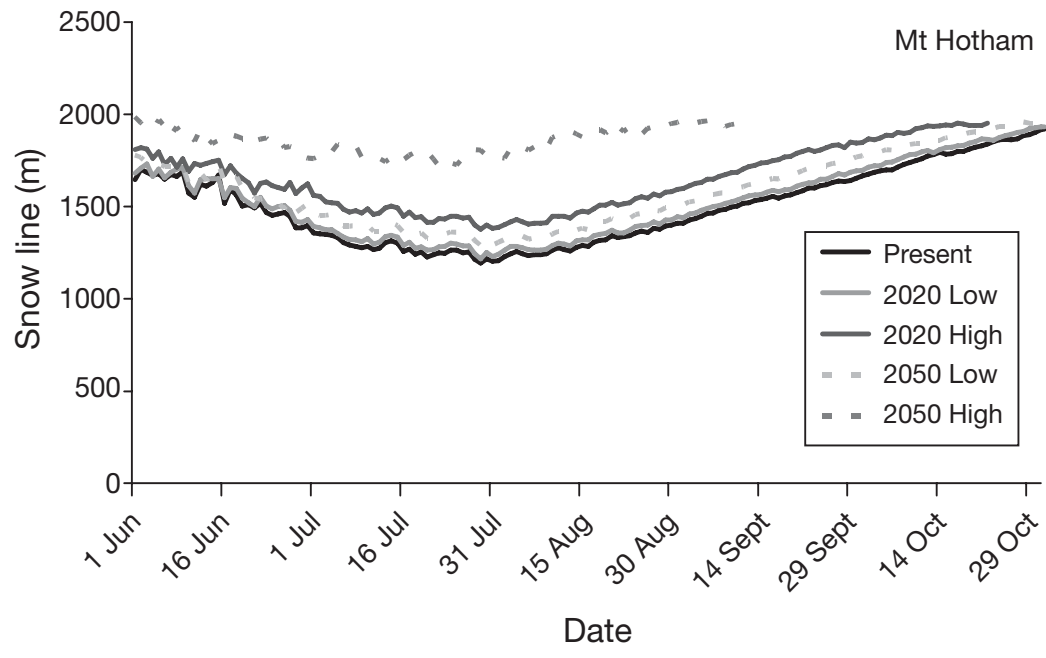

Fig. 6. Simulated average snow-line elevation for Mount Hotham for Present (1979-1998), and the 2020 and 2050 low- and high-impact scenarios. High impact scenarios are truncated when no snow is simulated 


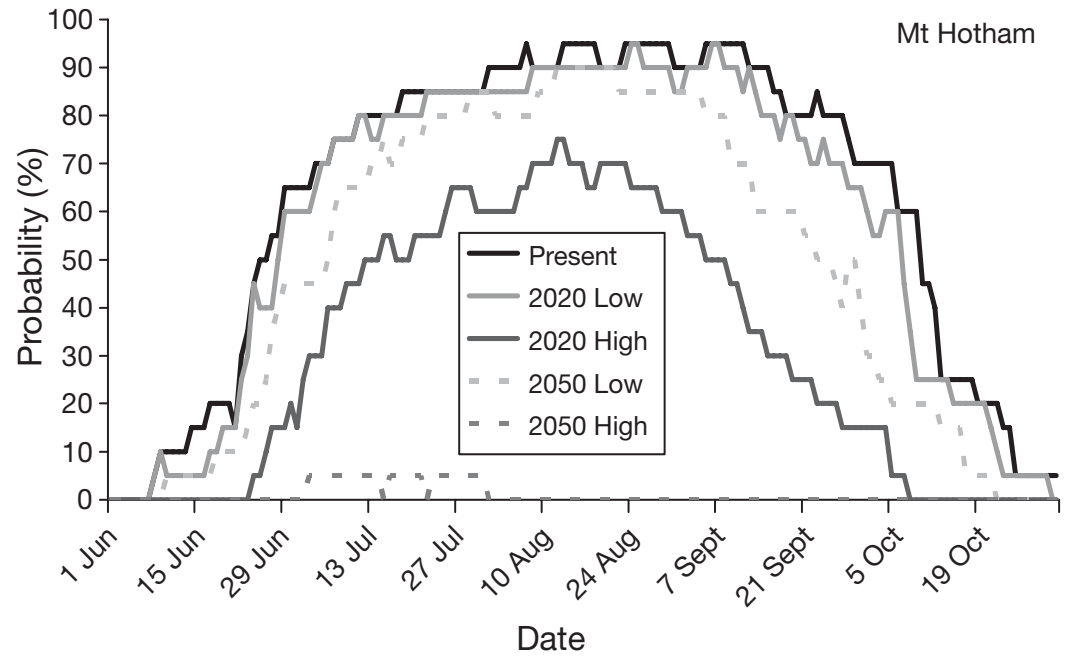

Fig. 7. Simulated profiles of the probability of $>30 \mathrm{~cm}$ natural snow depth at Mount Hotham (elevation 1882 m) for the present (1979-1998), 2020 and 2050 high- and low-impact scenarios

ski runs and lift access areas (NSW NPWS 2001). Snow is usually guaranteed for the opening of the season in early June due to the availability of this technology. Snowmaking guns may be triggered automatically by sufficiently low wet-bulb temperatures, or operated manually with location, flow-rate and duration optimized to suit prevailing conditions. Some resorts selectively use nucleating agents to enhance snowmaking efficiency (NSW NPWS 2001). Snow fences and grooming are also important for creating and placing snow in the right location.

Scott et al. (2003) investigated the vulnerability of the southern Ontario (Canada) ski industry to climate change, including adaptation through snowmaking. They used a $17 \mathrm{yr}$ record of daily snow conditions and operations from a major ski area to calibrate a skiseason model including snowmaking. They also surveyed operational decision rules based on interviews with ski area managers. While the methodology of Scott et al. (2003) has many similarities to the present study, there are some important differences. Scott et al. (2003) assumed a target snow-depth profile of at least $50 \mathrm{~cm}$, and assumed that snow would be made if the dry-bulb temperature were less than $-5^{\circ} \mathrm{C}$ using current technology, whereas our study assumes $-2^{\circ} \mathrm{C}$. In their results, the average ski-season duration was projected to decline 0 to $16 \%$ by 2020 , requiring a compensating increase in snowmaking by 36 to $144 \%$. They concluded that southern Ontario ski areas could remain operational in a warmer climate within existing business planning and investment time horizons (into the 2020s).

Future demand for snowmaking will be influenced by the following: (1) fewer hours with temperatures cold enough for making snow; (2) less natural snow cover; (3) faster ablation of snow; (4) improvements in snowmaking technology and operations; (5) the effect of cold air drainage on snowmaking capacity at lower elevations; (6) the effect of topography and aspect on natural snow deposition; and (7) possible water supply limitations and increased demand for water and power.

Results are given for the effects of factors (1), (2) and (3). The effect of factor (1) is presented first, followed by results for the combination of factors (1), (2) and (3). The exclusion of factors (4) to (7) are limitations of this study.

\subsection{Impact of warming on snowmaking hours and volume}

Sub-zero wet-bulb temperatures are needed for snowmaking. Unlike dry-bulb temperature, wet-bulb temperature is influenced by humidity. Snowmaking managers at most Australian ski resorts were able to supply data for the number of hours with wet-bulb temperatures in the range -2 to $-12^{\circ} \mathrm{C}$, in $0.1^{\circ} \mathrm{C}$ intervals, for May to September in most years between 1997 and 2002. Temperatures are obviously lower at higher elevations, and this has a significant effect on the apparent snowmaking capacity of each resort. Hence, it is important to note the elevations at which the wetbulb temperatures were measured (Table 6). Data for Mount Perisher and Mount Buller are for a much higher elevation $(1720 \mathrm{~m})$ than data for other resorts (e.g. $1340 \mathrm{~m}$ at Mount Thredbo and Lake Mountain).

Table 6. Locations of sites at which wet-bulb temperatures were measured during May to September in specified years at each resort. No data were available for Mount Hotham

\begin{tabular}{|lclc|}
\hline Resort & Years & Site(s) & Elevation (m) \\
\hline Mt Perisher & $1997-2001$ & $\begin{array}{l}\text { Bottom of Perisher Express } \\
\text { Quad Chair }\end{array}$ & 1720 \\
Mt Thredbo & $1997-2001$ & $\begin{array}{l}\text { Valley Terminal weather station } \\
\text { Mt Selwyn }\end{array}$ & 1340 \\
Falls Creek & $1997-2001$ & New Chum Beginner Bowl & 1550 \\
Mt Buller & 1997 \& 2000 & Average of 5 sites & 1642 \\
Mt Baw Baw & $1998-2002$ & Bottom of Maltese Cross T Bar & 1720 \\
Lake Mountain & $1997-2002$ & Gerratys & 1460 \\
\hline
\end{tabular}


Wet-bulb warming scenarios for 2020 were derived from the output of 9 climate models and applied to the observed hourly wet-bulb temperature data at each resort by simply adding the mean climate change from the scenarios to these data. The warming was 0.2 to $0.9^{\circ} \mathrm{C}$ at Mount Hotham and Falls Creek, and 0.1 to $0.7^{\circ} \mathrm{C}$ at the other resorts. These changes are slightly less than those for dry-bulb temperature (Table 1) due to regional changes in humidity associated with greenhouse warming. The average number of hours suitable for snowmaking declines by 2 to $7 \%$ for the low impact scenario and by 17 to $54 \%$ for the high impact scenario (Fig. 8).

To assess the impact of fewer snowmaking hours on the volume of snow that could be made, some simplifying assumptions were made about snow guns and how they are used. Resort operators have access to a range of snow guns for making snow, each of which has different production characteristics. There are 2 basic types: air-water guns and fan guns. Each technology has strengths and weaknesses related to snow output, capital costs and operating costs. Most resorts have a mix of snowmaking equipment operating at different pressures and water temperatures, and either manually or automatically activated. In this study, it is assumed that automatic activation occurs at temperatures below $-2^{\circ} \mathrm{C}$ with unlimited water supply so that each gun operates at maximum capacity.

Snow gun specifications include the amount of water used $\left(\mathrm{l} \mathrm{s}^{-1}\right)$ for wet-bulb temperatures ranging from -2 to $-12^{\circ} \mathrm{C}$ (Hennessy et al. 2003). It is assumed that the snow guns operate at full capacity whenever weather conditions are suitable. At lower temperatures, more snow can be made and more water is used. To simplify

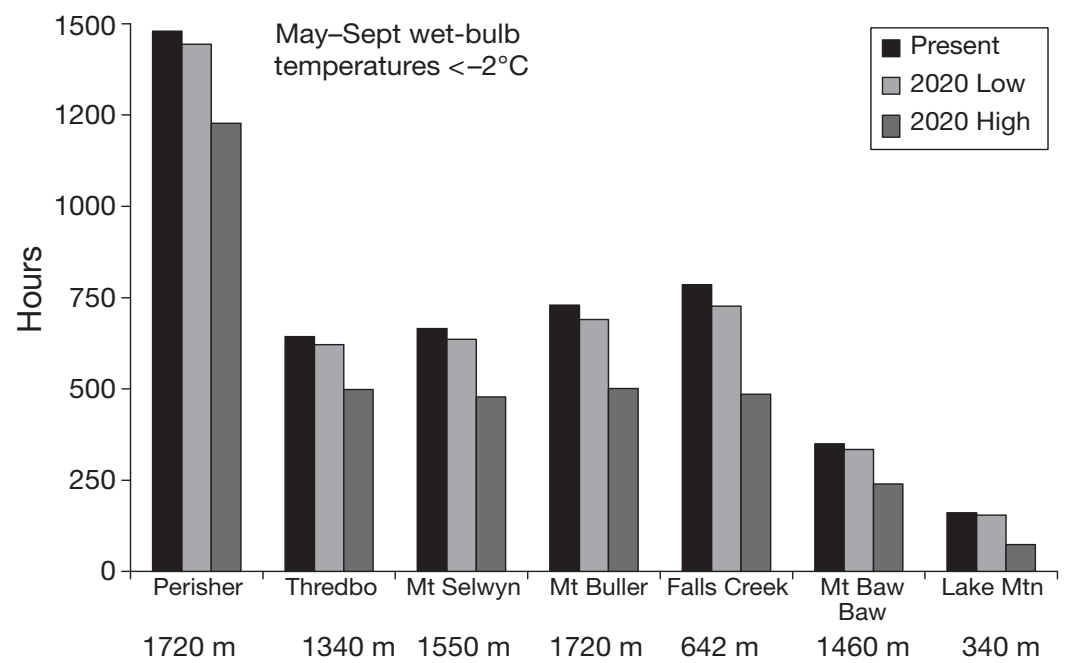

Fig. 8. Average number of hours during May to September when wet-bulb temperatures were $<-2{ }^{\circ} \mathrm{C}$ for the present (see years in Table 6) and 2020 low- and high-impact scenarios at 7 ski resorts. No wet-bulb temperatures were available for Mount Hotham calculations, our analysis was limited to the Brand A air-water gun and Brand B fan gun (brand names have been withheld for commercial reasons). At each resort, the wet-bulb temperatures were combined with waterflow specifications for each snow gun to estimate the amount of snow that could have been produced each year - this amount is defined as the potential volume $\left(\mathrm{V}_{\mathrm{P}}\right)$. As previously mentioned, an average snow density of 0.4 was used to convert water volumes to snow volumes.

Brand A snow guns produced more snow at each resort than Brand B. Under the present climate, Mount Perisher showed the best snowmaking capacity since it had the lowest wet-bulb temperatures. On average each year, Mount Thredbo, Mount Selwyn, Mount Buller and Falls Creek could produce about $20000 \mathrm{~m}^{3}$ snow-gun ${ }^{-1}$ using Brand A snow guns, and about $15000 \mathrm{~m}^{3}$ snow-gun ${ }^{-1}$ using Brand B. Mount Baw Baw could produce about half these amounts, and Lake Mountain could produce about one quarter. For both snow-gun types, the potential snow volumes are reduced by 3 to $10 \%$, and 18 to $55 \%$ under the lowand high-impact scenarios for 2020, respectively. Further details are provided by Hennessy et al. (2003).

\subsection{Adapting to warming through increased snowmaking}

The snowmaking manager at each resort nominated a target depth profile for natural plus manufactured snow, to be achieved in $90 \%$ of years. The target profile is the amount of snow needed by a particular time of year to ensure the successful long-term operation of the resort, and thus it differs from the minimum skiable depth. For example, at Mount Perisher, Mount Thredbo and Falls Creek, the depth profile was defined as $1 \mathrm{~cm}$ by 1 June, $30 \mathrm{~cm}$ by 30 June, $60 \mathrm{~cm}$ by 31 July, $100 \mathrm{~cm}$ by 31 August and $40 \mathrm{~cm}$ by 30 September (Table 7). Shallower profiles were specified for Mount Buller, Mount Selwyn and Lake Mountain, reflecting their less abundant natural snow cover. The CSIRO daily snow model was modified to calculate the amount of man-made snow required to achieve these target depths, allowing for natural snowfall, ablation and the pre-existing natural snow-depth, as shown for Mount Hotham in 1997 in Fig. 9.

The snow model simulated the daily man-made snow required to meet the target depth profiles from 1950 to 1998 
Table 7. Target snow depth profiles defined by snowmaking managers at each ski resort. Results for Mount Hotham and Mount Baw Baw are not shown since monthly wet-bulb temperature data were unavailable. ${ }^{*} 15$ Sept

\begin{tabular}{|lccccc|}
\hline \multirow{2}{*}{ Resort } & \multicolumn{5}{c}{ Target snow depth (cm) } \\
\cline { 2 - 6 } & 1 June & 30 June & 31 July & 31 August & \multirow{2}{*}{ 30 Sept } \\
\hline Mt Perisher & 1 & 30 & 60 & 100 & 40 \\
Mt Thredbo & 1 & 30 & 60 & 100 & 40 \\
Mt Selwyn & 1 & 20 & 30 & 45 & $0^{*}$ \\
Falls Creek & 1 & 30 & 60 & 100 & 40 \\
Mt Buller & 1 & 30 & 50 & 90 & 20 \\
Lake Mountain & 1 & 30 & 30 & 30 & $0^{*}$ \\
\hline
\end{tabular}

cover a typical ski run, the man-made target depth is multiplied by the ski run area. For example, at Mount Hotham, the June target depth is $43.4 \mathrm{~cm}$, so $8687 \mathrm{~m}^{3}$ of snow would be required to cover a typical ski run in $90 \%$ of Junes. This was defined as the target volume $\left(V_{T}\right)$ for Mount Hotham. Different ski resorts had different $V_{T}$, based on the combination of site-specific natural snowfall, snow-melt and target snow depths. To estimate the number of snow guns needed, the $\mathrm{V}_{\mathrm{T}}$ (snow demand) was divided by $\mathrm{V}_{\mathrm{P}}$ (snow

at each resort. For each month, the daily man-made snow depths were summed, and the totals were ranked from highest to lowest over the $49 \mathrm{yr}$ of record. The accumulated monthly depth exceeded in $90 \%$ of years is the 5th greatest depth in 49 years - this value defined the target snowmaking depth for each month. According to the simulations, June and September were the months in which most man-made snow was needed. For example, at Mount Hotham, an accumulation of $43.4 \mathrm{~cm}$ of man-made snow in June was required to ensure that $90 \%$ of Junes reached the target snow depth profile.

A typical downhill ski run on Australian mountains is about $500 \mathrm{~m}$ long and $40 \mathrm{~m}$ wide, with an area of $20000 \mathrm{~m}^{2}$. This area corresponds to a portion of a cross-country ski run, typically $2 \mathrm{~km}$ long $\times 10 \mathrm{~m}$ wide. To compute the volume of man-made snow required to

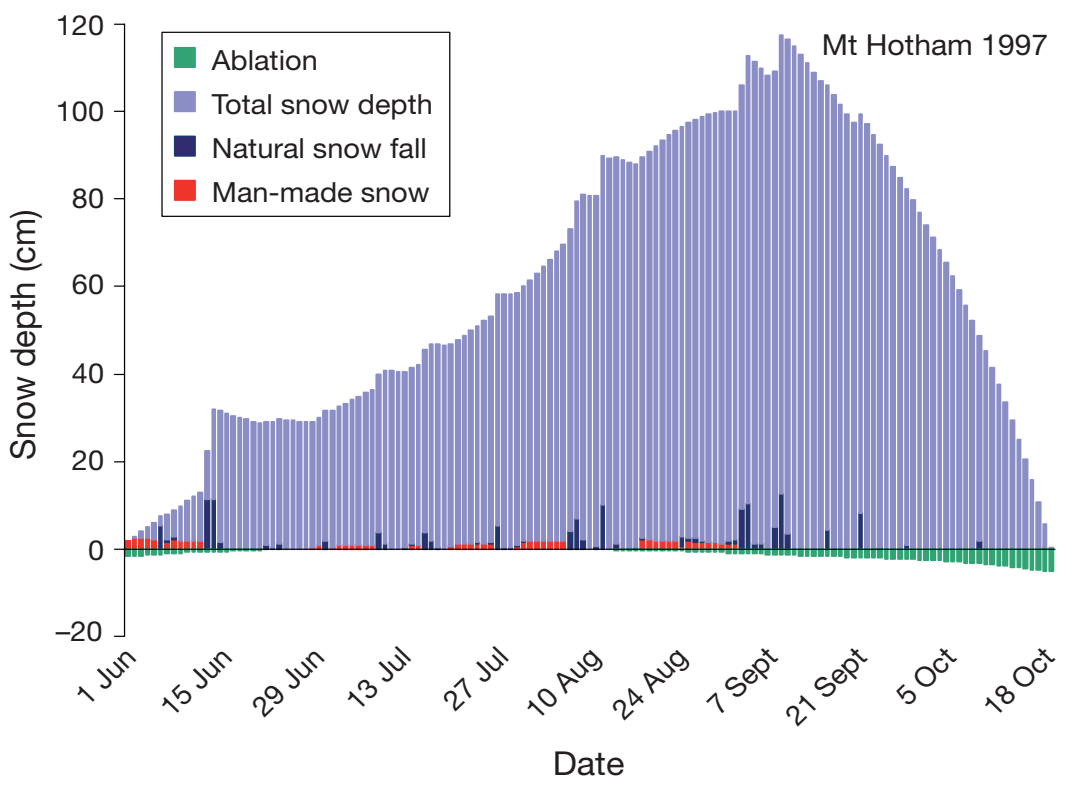

Fig. 9. Simulated daily snowfall, ablation, and man-made snow required to meet the target snow-depth profile at Mount Hotham from 1 June to 30 September 1997. The target depths are $30 \mathrm{~cm}$ on 30 June, $60 \mathrm{~cm}$ on 31 July, $100 \mathrm{~cm}$ on 31 August and $40 \mathrm{~cm}$ on 30 September supply), under present and 2020 conditions. This was done for June and September.

As noted above, the results are significantly influenced by the elevations at which snowmaking hours were computed (Table 6). Under the present conditions, about one Brand A gun per ski-run is needed at Mount Perisher, 1.8 at Falls Creek, and almost 3 at Mount Selwyn and Mount Buller (Fig. 10). At Lake Mountain, 15 Brand A guns per ski-run are needed. An increase of 11 to $24 \%$ in the number of these snow guns is required under the low impact scenario for 2020. Under the high impact scenario for 2020, a 73 to $200 \%$ increase in snow guns is needed, with the highest increases at low altitude. Of course, different results would be obtained if different target snow-depth profiles were specified in Table 7.

For Brand B guns, under the present conditions, about one Brand B gun per ski-run is needed at Mount Perisher, 2.6 at Falls Creek and Mount Thredbo, 4.2 at Mount Selwyn and Mount Buller, and 21 at Lake Mountain. An increase of 11 to $27 \%$ in the number of these snow guns would be required under the low impact scenario for 2020. Under the high impact scenario for 2020, a 71 to $188 \%$ increase in Brand B snow guns is needed.

A comparison of future snowmaking requirements that is independent of the type of snow gun used is the change in the percentage of required snow volume needed to be generated. These changes, along with current snow making volumes per run needed to meet the target volumes at each resort, are given in Table 8. Increases range from 5 to $17 \%$ for the 2020 low impact scenario to 23 to $62 \%$ for the 2020 high impact scenario. 


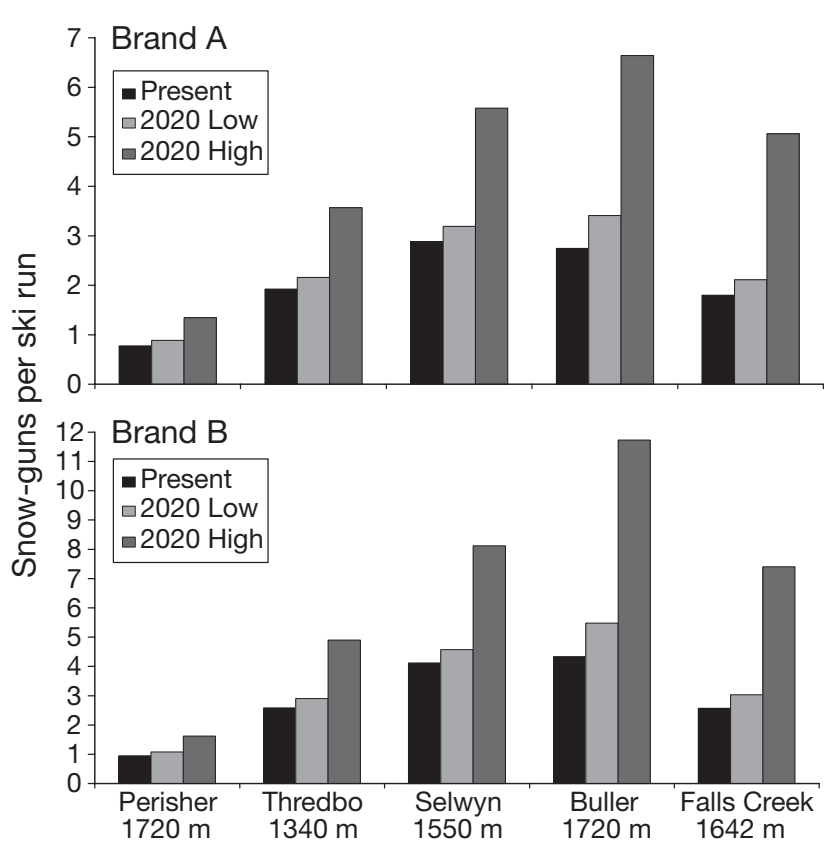

Fig. 10. Number of Brand A or Brand B snow guns needed to achieve resort-specific target snow-depth profiles (see Table 7) in $90 \%$ of Junes on a typical downhill ski run measuring $500 \mathrm{~m} \times 40 \mathrm{~m}(2000 \mathrm{~m} \times 10 \mathrm{~m}$ for a cross-country run), for the present (1950-1998) and 2020 low- and high-impact scenarios

Table 8. Present (1979-1998) snow making volume per ski run required to meet the target snow depth profiles in Table 7 , and predicted percentage increase in volume required for the 2020 low- and high-impact scenarios

\begin{tabular}{|lccc|}
\hline \multirow{2}{*}{ Resort } & Present $\left(\mathrm{m}^{3}\right)$ & \multicolumn{2}{c|}{ Predicted increase (\%) } \\
& & 2020 low & 2020 high \\
\hline Mt Perisher & 38838 & +11 & +42 \\
Mt Thredbo & 42947 & +8 & +43 \\
Mt Selwyn & 57326 & +5 & +34 \\
Falls Creek & 41587 & +7 & +62 \\
Mt Buller & 59046 & +17 & +61 \\
Lake Mountain & 67710 & +6 & +23 \\
\hline
\end{tabular}

\section{DISCUSSION AND CONCLUSIONS}

Warming trends at 4 Australian alpine sites over the past $35 \mathrm{yr}$ appear to be greater than trends at lower elevations. This effect was noted by Giorgi et al. (1997) in their study of the possible effects of climate change in the European Alps. They attributed it to a change in the height of the snowline. This may be consistent with observed declines in Australian late-season snow depths, although more data are needed to confirm this. There is also evidence of small increases in precipitation in the northern Australian alpine region over the past $50 \mathrm{yr}$ and small decreases in the southern Aus- tralian alpine region. A weak decline in maximum snow depth since the 1950s is evident at 3 of the 4 alpine sites analysed. This is consistent with the findings of Nicholls (2005). The moderate decline in snow depths in August and September at 3 sites may reflect a tendency for mid- to late-season snow depth to be driven by ablation while early season snow depth is driven by precipitation.

The potential impact of future climate change on Australian snow conditions was estimated for the years 2020 and 2050, based on CSIRO climate change projections used in a climate-driven snow model. In the following discussion, ranges of change are based on uncertainty in the projections and variations in snow responses between sites. The latter is quantified where there are distinct differences between low and high elevation responses. By 2020, the total area with an average of $\geq 1 \mathrm{~d}$ of snow cover decreases 10 to $39 \%$. The average snowseason length becomes 5 to $50 \mathrm{~d}$ shorter, which represents a 10 to $60 \%$ reduction at sites below, and 5 to $30 \%$ at sites above, $1600 \mathrm{~m}$. Peak snow depths decline by 15 to $80 \%$ at sites below, and by 5 to $50 \%$ at sites above, $1600 \mathrm{~m}$; with a tendency for maximum snow depth to occur earlier in the season. By 2050 , the total area with an average of $\geq 1 \mathrm{~d}$ of snow cover decreases 22 to $85 \%$. The average season length decreases by 15 to $110 \mathrm{~d}$, which represents a 30 to $99 \%$ reduction at sites below, and 15 to $95 \%$ at sites above, $1600 \mathrm{~m}$. Reductions in peak depths range from 10 to $100 \%$.

The snowline is expected to rise with climate change. For example, at Mount Kosciuszko, the snowline elevation on 1 September may rise from the present average of $1460 \mathrm{~m}$ to between 1490 and $1625 \mathrm{~m}$ by 2020 . The probability of exceeding a natural snow depth of $30 \mathrm{~cm}$ each day also declines with greenhouse warming. For example, at Mount Hotham on 1 July, the probability drops from the present value of $65 \%$ to 15 to $60 \%$ by 2020 .

Adaptation to climate change will be necessary at all ski resorts if snow cover and season length are to be maintained at or near today's levels. An obvious strategy is to make more snow using snow guns. Based on snowmaking specifications for 2 types of snow guns (Brand A and Brand B, see Section 5.2), and hourly wet-bulb temperature data over 5 yr at 6 resorts, the average number of hours suitable for snowmaking was estimated. By the year 2020, the number of hours declines by 2 to $7 \%$ for the low impact scenario and by 17 to $54 \%$ for the high impact scenario. The potential snowmaking volume per snow gun is reduced by 3 to $10 \%$ under the low impact scenario, and by 18 to $55 \%$ under the high impact scenario. These results are significantly influenced by the elevations at which snowmaking hours were computed. 
Based on target snow-depth profiles nominated by snowmaking managers at each resort, the snow model simulated the amount of man-made snow required each day, taking into account natural snowfall, snowmelt and the pre-existing natural snow depth. The required man-made snow was expressed as snow demand $\left(\mathrm{V}_{\mathrm{T}}\right)$ and compared with the snow supply $\left(\mathrm{V}_{\mathrm{P}}\right)$ that could be made per snow gun. Dividing $V_{T}$ by $V_{P}$ per snow gun gave an estimate of the number of snow guns needed to achieve the target depth profiles.

An increase of 11 to $24 \%$ in the number of Brand A snow guns would be required by 2020 for the low impact scenario, and 73 to $200 \%$ for the high impact scenario. An increase of 11 to $27 \%$ in the number of Brand B snow guns would be required by 2020 for the low impact scenario, and 71 to $188 \%$ for the high impact scenario. These translate into total snow volume increases of 5 to $17 \%$ for the low impact scenario and 23 to $62 \%$ for the high impact scenario. These percentage increases are somewhat lower than those estimated by Scott et al. (2003) for Ontario in the 2020s. Therefore, with sufficient investment in snow guns, the Australian ski industry should be able to manage the impact of projected climate change until at least 2020, bearing in mind the limitations outlined below.

As indicated in Sections 2, 4.2 and 5.1, the distribution of flora and fauna is expected to change under greenhouse climate conditions at the Australian subcontinental level (Brereton et al. 1995) and in the alpine region (Green \& Pickering 2002). Snow conditions, depth and snowline can have important implications for the distribution and persistence of biodiversity in the alpine area, so identification of potential changes in conditions can inform future management. It is likely that there will be both negative and positive impacts on the flora, with increases in the occurrence and distribution of several dominant plant communities (tall alpine herbfield, heathland and sod-tussock grassland) and, as a consequence, decreases in the much smaller areas of the more sensitive communities, particularly the short alpine herbfield and groundwater communities (fens, bogs and peatlands) that are of particular significance for catchments (Pickering et al 2004). Impacts on native fauna are likely to include decreased distribution and abundance of the alpine endemic she-oak skink, mountain pygmy-possum and the broad-toothed rat, which have narrow environmental tolerances (Green \& Pickering 2002, Pickering et al. 2004). The diversity and abundance of birds may increase with warming. Increased use of snow manipulation techniques by ski resorts is likely to have negative effects on the vegetation, soils and hydrology of subalpine-alpine areas within ski resorts (Pickering et al. 2004).
This study made some simplifying assumptions and excluded a number of physical and management effects that are not easily included in the CSIRO modeling framework. Apart from limiting results to 2 snow guns, operated automatically at all resorts, exclusions were as follows: (1) likely improvements in snowmaking technology; (2) improvements in snowmaking operations, e.g. optimizing start-up temperatures, managing the number of pumps and pressure gradients to minimize water heating, improving efficiency of water cooling systems, plume placement, elevating guns on towers, additives to enhance conversion of water to snow, snow grooming and snow-farming, the effect of cold air drainage on snowmaking capacity at lower elevations; (3) effect of topographic aspect on natural snow deposition; (4) reduced ablation rate for man-made snow relative to natural snow; (5) possible water-supply limitations due to projected climate change; (6) acceptable levels of environmental impact, e.g. likely increase in demand for water and energy due to increased snowmaking. There is significant potential to widen the scope of the present study, and to address uncertainties and gaps in knowledge, through further research.

Accuracy of the modeling of natural snow cover could be improved by using daily, rather than monthly, temperature data if reliable daily data were available. However, without significant additions to the existing observation network, daily temperature and precipitation extremes are likely to be under-represented in daily interpolated fields which always impose a degree of spatial averaging. Hence, rates of exceedence of daily extremes are likely to be more reliably represented by incorporating the standard deviation with the monthly interpolated fields as done here. If available, daily data would allow more accurate estimation of the proportion of precipitation falling as snow, and would be likely to improve snow simulation in southern areas of the alpine region where the current methods based on monthly data are likely to be less reliable. More generally, simulations of year to year and withinyear fluctuations in snow depth would be improved. It would also allow full integration of the modeling of natural and man-made snow. This type of approach was used in the Canadian study by Scott et al. (2003). Allowance should be made for differing ablation rates of man-made and natural snow in the modeling system. Plainly, there is also a need for more reliable high altitude precipitation data in southern Victoria.

In this study, it was assumed that the same rate of projected warming applied to maximum and minimum temperatures because only mean temperature projections were available from 9 climate models. During the relatively dry winter of 2006 in southeastern Australia, there were many clear nights, leading to more anom- 
alously low minimum temperatures suitable for snowmaking and more anomalously warm days with high rates of ablation. The potential for an increase in the diurnal temperature range was not included in this study, so the frequency of temperatures cold enough for snowmaking may have been under-estimated, but the rate of ablation may have also been underestimated. The net effect on snowmaking demand and supply needs to be assessed.

In future studies, it would be beneficial to consider the water supply and energy implications of increased snowmaking. Comparison with impacts in other skiing regions such as New Zealand, Canada, USA and Europe could also be considered.

Acknowledgements. This study was supported by: the Victorian Department of Sustainability and Environment, the Victorian Greenhouse Office, Parks Victoria, the New South Wales National Parks and Wildlife Service, the New South Wales Department of Infrastructure, Planning and Natural Resources, the Australian Greenhouse Office, and the Australian Ski Areas Association. Snow depth data were supplied by Southern Hydro for Rocky Valley Dam from 1935 to 2002, and by the Snowy Mountains Hydroelectric Authority (www.snowyhydro.com.au/data/pdf/snowdepths.pdf) for Spencers Creek (1954-2002), Deep Creek (1957-2002) and Three Mile Dam (1955-2002). The climate model data were generously provided by climate modellers at CSIRO, the Canadian Climate Centre, Deutsches Klimarechenzentrum, Hamburg, the US Geophysical Fluid Dynamics Laboratory, the US National Center for Atmospheric Research, and the UK Hadley Centre for Climate Prediction and Research. Dr D. Etheridge (CSIRO) provided useful comments on the manuscript, as did 2 anonymous reviewers.

\section{LITERATURE CITED}

Abegg B (1996) Klimaänderung und Tourismus. Klimafolgenforschung am Beispiel des Wintertourismus in den Schweizer Alpen. Schlussbericht NFP 31 (im Rahmen des Nationalen Forschungsprogrammes 'Klimaänderungen und Naturkatastrophen'). vdf, Hochschulverlag an der ETH, Zürich

ARCC (Alpine Resorts Co-ordinating Council) (2007) Victoria Alpine Resorts winter 2006 end of season report. Alpine Resorts Co-ordinating Council, East Melbourne. Available at: www.arcc.vic.gov.au/documents/ReportWinter2006 EndofSeasonTextandFigures_-_AS_PUBLISHED.pdf

Brereton R, Bennett S, Mansergh I (1995) Enhanced greenhouse climate change and its potential effect on selected fauna of south-east Australia. Biol Conserv 72:339-354

Brown RD (2000) Northern hemisphere snow cover variability and change, 1915-97. J Clim 13:2339-2355

Bürki R (2000) Klimaänderung und Anpassungsprozesse im Wintertourismus. Neue Reihe, Heft 6. Ostschweizerische Geographische Gesellschaft, St. Gallen

CIAP (Climate Impact Assessment Program) (1975) Impacts of climatic change on the biosphere. CIAP monograph 5, Part 2: climate effects. Department of Transportation, CIAP, Washington, DC

CSIRO (Australian Commonwealth Scientific and Research Organisation) (1996) 1996 climate change scenarios.
CSIRO Atmospheric Research, Aspendale. Available at: www.dar.csiro.au/impacts/future.html

CSIRO (Australian Commonwealth Scientific and Research Organisation) (2001) Climate change projections for Australia. CSIRO Atmospheric Research, Aspendale. Available at: www.cmar.csiro.au/e-print/open/projections2001. pdf.

Davis CJ (1998) Meteorological aspects of snow. In: Green K (ed) Snow: a natural history, an uncertain future. Australian Alps Liaison Committee, Canberra, p 3-34

Elsasser H, Bürki R (2002) Climate change as a threat to tourism in the Alps. Clim Res 20:253-257

Galloway RW (1988) The potential impact of climate changes on Australian ski fields. In: Pearman GI (ed) Greenhouse: planning for climate change. CSIRO/Brill, Melbourne, p 428-437

Giorgi F, Hurrell JW, Marinucci MR, Beniston M (1997) Elevation dependency of the surface climate change signal: a model study. J Clim 10:288-296

Green K (2000) Snow trend. Aust Inst of Alpine Stud Newsl 9 (August). Available at: www.aias.org.au/newsletters/ newslet9.html\#trend

Green K, Pickering CM (2002) A scenario for mammal and bird diversity in the Snowy Mountains of Australia in

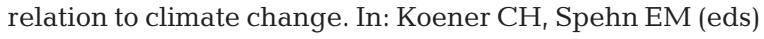
Mountain biodiversity: a global assessment. Parthenon, London, p 241-249

Groisman PY, Knight RW, Karl TR, Easterling DR, Sun B, Lawrimore JH (2004) Contemporary changes of the hydrological cycle over the contiguous United States: trends derived from in situ observations. J Hydrometeorol 5:64-85

Haylock MR, Whetton PH, Desborough C (1994) Climate change and snow cover duration in the Victorian Alps. EPAV Publication No. 403, EPAV, Melbourne

Hennessy KJ, Whetton $\mathrm{PH}$, Bathols J, Hutchinson $\mathrm{M}$, Sharples J (2003) The impact of climate change on snow conditions in Australia. Consultancy report for the Victorian Dept of Sustainability and Environment, NSW National Parks and Wildlife Service, Australian Greenhouse Office and the Australian Ski Areas Association. CSIRO Atmospheric Research, Aspendale. Available at: www.cmar.csiro.au/e-print/open/hennes sy_2003a.pdf

Hutchinson MF (1991) The application of thin plate smoothing splines to continent-wide data assimilation. In: Jasper JD (ed) Data assimilation systems: papers presented at the 2nd BMRC Model Workshop, September 1990. Bureau of Meteorology, Melbourne, p 104-113

Hutchinson MF (2001) ANUSPLIN Version 4.2. Centre for Resource and Environmental Studies, Australian National University. Available at: http://cres.anu.edu.au/outputs/ anusplin.php

IPCC (Intergovernmental Panel on Climate Change) (2000) Special report on emissions scenarios (SRES). Special Report of the IPCC Working Group III. WMO/UNEP. Available at: www.ipcc.ch/pdf/special-reports/spm/sres-en.pdf

IPCC (Intergovernmental Panel on Climate Change) (2001) Climate change 2001: the scientific basis - summary for policymakers and technical summary of the Working Group I Report. WMO/UNEP, Cambridge University Press, Cambridge

Jones PD, Moberg A (2003) Hemispheric and large-scale surface air temperature variations: an extensive revision and an update to 2001. J Clim 16:206-223

McKenney DW, Pedlar JH, Papadopol P, Hutchinson MF (2006) The development of 1901-2000 historical monthly climate models for Canada and the United States. Agric For Meteorol 138:69-81 
Mitchell TD (2003) Pattern scaling: an examination of the accuracy of the technique for describing future climates. Clim Change 60:217-242

Mote PW, Hamlet AF, Clark MP, Lettenmaier DP (2005) Declining mountain snowpack in western North America. Bull Am Meteorol Soc 86:39-49

Nicholls N (2005) Climate variability, climate change and the Australian snow season. Aust Met Mag 54:177-185

Nicholls N, Collins D (2006) Observed change in Australia over the past century. Energy Environ 17:1-12

NSW NPWS (New South Wales National Parks and Wildlife Service) (2001) Recovery plan for the mountain pygmypossum (Barramys parvus). Draft NSW Recovery Plan for Public Comment. NSW National Parks and Wildlife Service, Hurstville

Pickering C, Good R, Green K (2004) Potential effects of global warming on the biota of the Australian Alps Australian Greenhouse Office, Canberra. Available at: www.greenhouse.gov.au/impacts/publications/alps.html

Robinson DA, Frei A (2000) Seasonal variability of northern hemisphere snow extent using visible satellite data. Prof Geogr 52:307-315

Ruddell AR, Budd WF, Smith IN, Keage PL, Jones R (1990) The south-east Australian alpine climate study: A report by the Meteorology Department, University of Melbourne, for the Alpine Resorts Commission. University of Melbourne

Editorial responsibility: Bryson Bates, Wembley, WA, Australia
Scott D, McBoyle G, Mills B (2003) Climate change and the skiing industry in southern Ontario (Canada): exploring the importance of snowmaking as a technical adaptation. Clim Res 23:171-181

Sevruk B (1982) Methods of correction for systematic error in point precipitation measurement for operational use. Operational Hydrology Report No. 21, WMO, Geneva

Slater A (1995) Snow in Australia: trends and variability. BSc thesis, Macquarie University, Sydney. Available at: http:// cires.colorado.edu/ aslater/snowy.html

Steiger R (2004) Klimaänderung und Skigebiete im bayerischen Alpenraum. Dipl. Arb. thesis. Universität Innsbruck, Institut für Geographie

Stewart IT, Cayan DR, Dettinger MD (2005) Changes towards earlier streamflow timing across western North America. J Clim 18:1136-1155

Whetton PH (1998) Climate change impacts on the spatial extent of snow-cover in the Australian Alps. In: Green K (ed) Snow: a natural history, an uncertain future. Australian Alps Liaison Committee, Canberra, p 195-206

Whetton PH, Haylock MR, Galloway RW (1996) Climate change and snow-cover duration in the Australian Alps. Clim Change 32:447-479

WMO (2005) WMO statement on the status of the global climate in 2005. World Meteorological Organisation, Geneva. Available at: www.climatecentre.org/downloads/ File/articles/Article\%20WMO\%202005.pdf

Submitted: September 19, 2006; Accepted: September 18, 2007 Proofs received from author(s): December 5, 2007 